\title{
Pengembangan Aplikasi CIKUR Untuk Mengidentifikasi Blind Code Tactile Effect Terhadap Penyandang Disabilitas Tunanetra di SLB Pembina Sulawesi Selatan
}

\author{
Moghina Fahmi ${ }^{1}$, Zulhajji ${ }^{2}$, Jumadi ${ }^{3}$ \\ Prodi Pendidikan Teknik Informatika dan Komputer, Universitas Negeri Makassar \\ Jalan Tamalate V No.78 Makassar \\ 1fahmighina@gmail.com \\ 2ajiimuda@yahoo.co.id \\ 3jparenreng@unm.ac.id
}

\begin{abstract}
This research is a research and development (Research and Development) with a prototype development model. The research objective is the development of the CIKUR application for blind students, knowing the appropriateness of the application, and knowing the user's response to the application development. Research data obtained from interviews, observations, and questionnaires by respondents. Application test results are obtained by analyzing aspects of functionality and usability based on ISO 25010 standards. The results of the CIKUR application development are in the form of two main components namely the scan menu and the about menu. From the results of testing the functionality obtained eligibility of applications with a percentage of $100 \%$ with a category acceptable. The usability test results obtained a percentage of $90 \%$ with a frequency of 18 and included in the category of strongly agree. Then the percentage of $10 \%$ with a frequency of 2 and included in the agreed category
\end{abstract}

Keywords - CIKUR, Disability, Blind Code Tactile Effect.

\section{Pendahuluan}

\section{A. Latar Belakang}

Di Indonesia, peredaran dan penggunaan uang di masyarakat sebagai alat pemenuhan kebutuan masyarakat senantiasa diperhatikan dan diawasi oleh Bank Indonesia sebagai Bank Sentral Republik Indonesia, guna menjaga dan memelihara kestabilan nilai rupiah. Sebagai lembaga independen yang diberikan tugas dan kewenangan dalam mengeluarkan alat pembayaran yang sah, dalam hal ini uang rupiah tentunya memberikan pengaruh terhadap seluruh aktivita kegiatan ekonomi suatu negara. Bank Indonesia sebagai otoritas moneter senantiasa mengeluarkan berbagai kebijakan-kebijakan terhadap aktivitas ekonomi di masyarakat dalam rangka mengatur dan menjaga kelancaran sistem pembayaran.

Salah satu kebijakan terbaru Bank Indonesia dalam kaitannya dengan uang rupiah adalah mengeluarkan uang rupiah Tahun Emisi (TE) 2016 yang telah diresmikan tulisan BI, benang pengaman, dan gambar tersembunyi multiwarna (multicolour latent image).

Sebagaimana kita ketahui bahwa penyandang tunanetra memiliki keterbatasan penglihatan yang tentunya sangat berpengaruh terhadap komunikasi dan interaksi dengan orang pengeluaran dan pengedarannya pada tahun yang sama. Kebijakan ini bukan tanpa alasan, sebab Bank Indonesia dan pemerintah memperbaharui uang rupiah sebagai spirit baru bagi masyarakat Indonesia dalam melakukan transaksi. Tidak hanya itu, fisik uang rupiah TE 2016 memiliki perbedaan yang signifikan dengan uang rupiah yang sebelumnya lebih dulu berlaku sebagai alat pembayaran yang sah di Indonesia. Selain kualitas cetak berteknologi tinggi dan kesegaran gambar, uang rupiah TE 2016 juga dilengkapi dengan pengaman berbasis teknologi guna memerangi dan menghambat maraknya peredaran uang palsu di masyarakat. Beberapa unsur pengaman rupiah diantaranya kode tuna netra (blind code) berupa pasangan garis di sisi kanan dan kiri, tanda air (watermark) berupa gambar pahlawan dan ornamen, gambar tersembunyi (latent image) pada tulisan BI dalam bingkai persegi panjang, gambar saling isi (rectoverso) pada logo BI yang terlihat secara utuh apabila diterawang ke arah cahaya, tinta berubah warna (colour shifting ink), gambar raster berupa tulisan NKRI yang dapat dibaca dengan bantuan kaca pembesar, mikroteks berupa

lain dalam hal-hal yang sifatnya visual yang menuntut berperan aktifnya fungsi penglihatan. Dalam persamaan kedudukan, penyandang tunanetra juga berhak untuk merasakan kesejahteraan berupa pemenuhan kebutuhan. Sehingga, para penyandang tuna netra dalam memenuhi kebutuhan tentunya 
melakukan transaksi jual beli layaknya masyarakat pada umumnya. Namun dalam perjalanannya, sebagian masyarakat masih khawatir dengan diresmikannya uang rupiah TE 2016 sebagai alat pembayaran yang sah di wilayah Negara Republik Indonesia. Hal ini tidak lepas dari kasus-kasus peredaran uang palsu yang terjadi sebelumnya, dan dikhawatirkan tetap akan terjadi meskipun dilakukan pembaharuan uang rupiah secara fisik. Terutama bagi penyandang tuna netra yang secara fisik lebih sulit membedakan mana uang rupiah yang asli dan uang rupiah yang palsu, sehingga ada keraguan dan ketakutan bila ingin memenuhi kebutuhan hidupnya.

Bank Indonesia sebelum dikeluarkannya uang rupiah TE 2016 sudah berupaya semaksimal mungkin dengan berbasis berpendidikan khusus yaitu dari TK-SMA antara lain penyandang disabilitas tunarungu, penyandang disabilitas tunadaksa, penyandang disabilitas tunagrahita, penyandang disabilitas autis, dan yang terakhir penyandang disabilitas tunanetra. Penyandang disabilitas khususnya tunanetra mengalami keterbatasan penglihatan yang berpengaruh terhadap penerimaan informasi visual saat berkomunikasi dan berinteraksi. Namun, setelah melakukan wawancara langsung kepada salah seorang guru kelompok A sekaligus beliau adalah seseorang yang dahulunya pernah mengenyam pendidikan pada kelompok A yaitu Bapak Hendra. Beliau mengatakan bahwa betul adanya ketika kondisi uang tersebut sudah lusuh maka blind code sulit untuk diraba dan sampai saat ini masih ada yang kesulitan membedakan nominal uang. Meskipun bapak Hendra mengalami keterbatasan dalam melihat tetapi beliau cakap teknologi dan paham dalam mengenali uang rupiah TE 2016.

Atas dasar itu, untuk mengisi kelemahan atau kekurangan blind code pada pecahan uang kertas TE 2016 bagi tuna netra, maka diperlukan suatu inovasi yang dapat membantu dan memudahkan penyandang tunanetra untuk mengenal nominal dan mampu membedakan uang yang asli dengan uang yang palsu. Inovasi tersebut tidak mengisyaratkan untuk melemahkan fungsi fisik dari uang rupiah TE 2016 secara umum, melainkan semata-mata membantu penyandang tunanetra yang masih kesulitan mengenali keaslian uang rupiah meskipun sudah dibekali tanda pengaman blind code tactile effect. Inovasi yang hendak dibuat adalah pengembangan aplikasi CIKUR dimana software ini berfungsi untuk membaca nominal uang yang berguna untuk memudahkan tunanetra mengenal nominal uang dan ciri-ciri keaslian uang rupiah TE 2016 dan jelas aplikasi ini juga berbasis android.

\section{KAJIAN PUSTAKA}

A. Tinjauan Pustaka teknologi, agar uang rupiah TE 2016 dapat dilengkapi dengan unsur pengaman yang sulit bagi pihak tertentu untuk memalsukannya. Meskipun hadirnya uang rupiah TE 2016 dapat menekan dan menghambat pengedaran uang palsu, namun di sisi lain bagi tunanetra masih kesulitan dalam menentukan nominal setiap pecahan uang kertas dan juga keaslian uang rupiah, terlebih bila uang tersebut sudah lusuh dan tidak lagi sesuai dengan larangan 5 jangan yang sering disosialisasikan oleh Bank Indonesia dalam rangka merawat uang rupiah.

SLB Pembina Sulawesi Selatan menjadi titik fokus penelitian ini dimana SLB Pembina Sulawesi Selatan melayani anak

1) Tunanetra: Pengertian tunanetra itu sendiri banyak ragamnya, sebab dapat ditunjau dari segi harfiah, kiasan, metafisika, medi, fungsional ataupun dari segi bahasa, kata tunanetra terdiri dari kata tuna dan netra. Menurut kamus besar bahasa Indonesia (Depdikbud, 1990: 971).

2) Uang: Mata Uang adalah uang yang dikeluarkan oleh Negara Kesatuan Republik Indonesia yang selanjutnya disebut Rupiah. Rupiah adalah mata uang yang berlaku di Negara Republik Indonesia. Sebagai alat pembayaran yang sah di Republik Indonesia ini, maka diharapkan kita dapat terhindar dari kejahatan pemalsuan uang. Selain uang rupiah yang kita ketahui, masih ada macam uang khusus, berupa uang kertas bersambung (uncut banknotes) dan koin peringatan (commemorative coins). Pasal 11 Undang-undang No.7 Tahun 2011 tentang Mata Uang memberikan mandat bagi Bank Indonesia menjadi satu-satunya lembaga yang berwenang melakukan pengeluaran, pengedaran, dan pencabutan Rupiah. (DPU BI, 2011).

3) Augmented Reality: Menurut Devi Oktaviani (2013:7) , Augmented Reality (AR) adalah teknologi yang menggabungkan benda nyata dua dimensi dan tiga dimensi ke dalam sebuah lingkungan nyata tiga dimensi lalu memproyeksikan benda-benda maya tersebut dalam waktu nyata. Tidak seperti realitas maya yang sepenuhnya menggantikan kenyataan, realitas bertambah sekedar menambahkan atau melengkapi kenyataan.

\section{B. Kerangka Pikir}

Mengenal ciri-ciri keaslian uang rupiah merupakan indikator yang sangat penting dalam mengenal uang Rupiah sebagai alat pembayaran yang sah di Wilayah Negara Indonesia. Hal tersebut juga memberikan manfaat dalam bidang pendidikan, salah satunya menambah wawasan bagi penyandang disabilitas terkait keaslian uang Rupiah. Sehingga, mereka dapat mengantisipasi terjadinya pemalsuan uang melalui edukasi keaslian uang Rupiah dan diharapkan turut 
andil dalam pencegahan peredaran uang palsu. Pada tampilan kerangka pikir terlihat bahwa fenomena yang terjadi penyandang disabilitas tunanetra ingin melakukan jual beli pada masyarakat sekitarnya menggunakan uang rupiah. Muncul empat permasalahan yaitu pemahaman pengetahuan tentang ciri-ciri keaslian uang bagi penyandang disabilitas sangat terbatas, lalu yang kedua membutuhkan bantuan orang lain untuk memberitahunkan jumlah nominal uangnya, yang ketiga berisiko terjadinya tindak laku penipuan saat bertransaksi. Dan yang terakhir kesulitan membedakan nominal uang ketika kondisi fisik uang yang masih baik ataupun kurang baik. Permasalahan-permasalahan ini disimpulkan setelah peneliti melakukan observasi dan wawancara kepada penyandang disabilitas tunanetra yang ada di SLB Pembina SUL-SEL. Solusi yang ditawarkan peneliti yaitu mensosialisasikan CIKUR (Ciri-ciri Uang Rupiah) kepada penyandang disabilitas dengan menggunakan aplikasi android. Solusi yang ditawarkan peneliti ditinjau dari permasalahan-permasalahan yang terjadi di lapangan secara nyata. Inilah yang menjadi landasan serta alasan yang kuat bagi peneliti untuk membuat judul skripsi yaitu Pengembangan Aplikasi CIKUR Untuk Mengidentifikasi Blind Code Tactile Effect Terhadap Penyandang Disabilitas Tunanetra Di SLB Pembina Sul - Sel. Berdasarkan latar belakang, maka penulis menggambarkan skema kerangka pikir yang ditunjukkan pada gambar berikutsiswa dapat lebih berfokus pada materi yang dipelajari yang tentunya diharapkan menghasilkan hasil belajar yang lebih baik. Kerangka pikir dalam penelitian ini dapat dilihat pada Gambar dibawah ini:

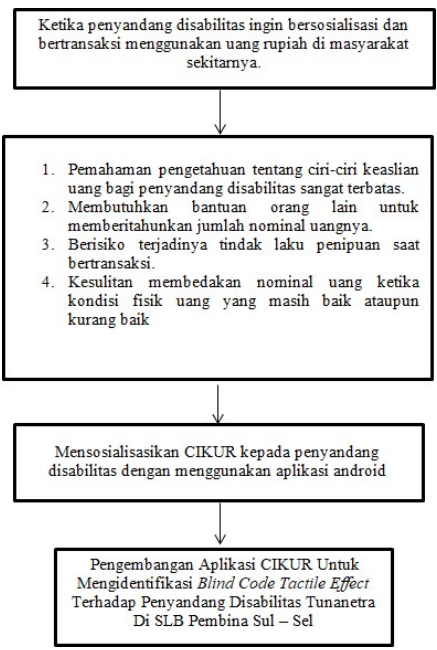

Gambar 1. Bagan Kerangka Pikir

III. METODE PENELITIAN
Penelitian ini merupakan penelitian dan pengembangan (Research and Development). Model R\&D merupakan jenis penelitian yang berorientasi pada pengembangan produk berupa pengembangan software yang dibuat pada aplikasi Unity. Pengembangan aplikasi yang dilakukan pada penelitian ini menghasilkan sebuah produk aplikasi CIKUR. Adapun tahapan penelitian dalam membangun Aplikasi CIKUR. Adapun tahapan penelitian dalam membangun Aplikasi CIKUR dilakukan dengan menggunakan metode prototype. Metode ini telah banyak digunakan oleh beberapa peneliti pengembang teknologi atau perangkat lunak. Model pengembangan ini merupakan proses interaktif dan berulangulang. Sehingga dilakukan beberapa kali tahap evaluasi sebelum penguji ahli menerima aplikasi tersebut. Selama pembuatan aplikasi, pengembang dan pengguna dapat saling berinteraksi, tidak mendefinisikan pada awal pengembangan tentang kebutuhan pengguna. Model pengembangan prototype dimulai dari pengumpulan kebutuhan atau menganalisis kebutuhan pengguna, pembangunan prototype, pengkodean, pengujian, dan pemeliharaan.

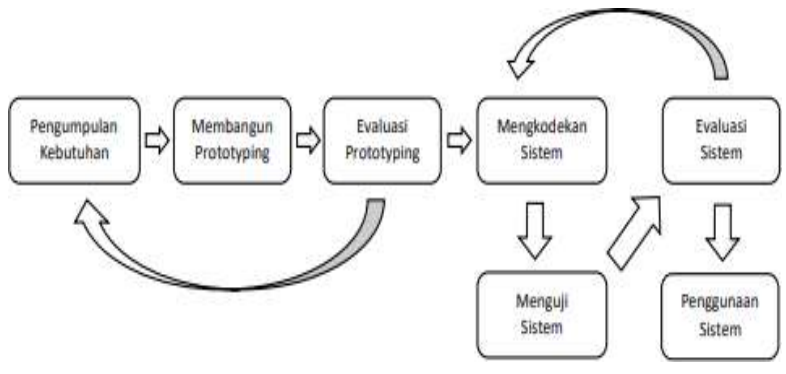

Gambar 2 Tahapan Model Pengembangan Prototype (sumber pressman, 2015)

\section{HASIL DAN PEMBAHASAN}

\section{A. Hasil Penelitian}

\section{Hasil Analisis Kebutuhan}

Data analisis kebutuhan yang telah dilakukan melalui wawancara dan observasi diperoleh hasil bahwa penyandang disabiltas tunanetra di SLB Pembina Sulawesi Selatan masih banyak yang belum memahami blind code uang rupiah maka penyandang disabilitas tunanetra masih sulit untuk membedakan nominal uang rupiah yang kondisi fisiknya masih dalam keadaan baik maupun dalam keadaan lusuh. Masalah yang terjadi di masyarakat SLB Pembina Sulawesi Selatan selain kurangnya edukasi terkait blind code adapun masalah lainnya yaitu keresahan para penyandang disabilitas tunanetra saat bertransaksi jual beli menggunakan uang rupiah di masyarakat karena khawatir adanya tindak laku kejahatan.

\section{Hasil Pengujian Sistem}


Uji validasi pada produk pengembangan ini melibatkan 5 orang ahli, yaitu 2 orang sebagai ahli instrumen, 2 orang ahli media, dan 1 orang ahli konten. 2 ahli media mewakili aspek functionality sutability ISO 25010.

TABEL I

Rangkuman hasil uji validasi instrument penelitian (functionality)

\begin{tabular}{|c|c|c|c|c|c|c|c|c|c|c|c|c|}
\hline \multirow{3}{*}{$\begin{array}{c}\text { No } \\
1\end{array}$} & \multirow{3}{*}{$\begin{array}{l}\begin{array}{c}\text { Nama } \\
\text { Validator }\end{array} \\
\text { Validator } \\
1\end{array}$} & \multicolumn{8}{|c|}{ Aspek Yang Dinilai } & \multirow{3}{*}{$\begin{array}{c}\begin{array}{c}\text { Jumlah } \\
\text { Skor }\end{array} \\
38\end{array}$} & \multirow{3}{*}{$\begin{array}{r}\text { Rerata } \\
4.75\end{array}$} & \multirow{3}{*}{$\begin{array}{c}\text { Kategori } \\
\begin{array}{c}\text { Sangat } \\
\text { Layak }\end{array}\end{array}$} \\
\hline & & \multicolumn{3}{|c|}{$\begin{array}{c}\text { Aspek } \\
\text { Petunjuk }\end{array}$} & \multicolumn{2}{|c|}{$\begin{array}{c}\text { Aspek } \\
\text { Isi }\end{array}$} & \multicolumn{3}{|c|}{$\begin{array}{c}\text { Aspek } \\
\text { Bahasa } \\
\end{array}$} & & & \\
\hline & & 5 & 4 & 5 & 5 & 5 & 4 & 5 & 5 & & & \\
\hline 2 & $\begin{array}{l}\text { Validator } \\
2\end{array}$ & 4 & 5 & 5 & 5 & 5 & 5 & 5 & 5 & 39 & 4.88 & $\begin{array}{l}\text { Sangat } \\
\text { Layak }\end{array}$ \\
\hline \multicolumn{11}{|c|}{ Rerata } & 4.81 & $\begin{array}{l}\text { Sangat } \\
\text { Layak }\end{array}$ \\
\hline
\end{tabular}

TABEL II

Rangkuman hasil uji validasi instrument penelitian (Usability)

\begin{tabular}{|c|c|c|c|c|c|c|c|c|c|c|c|c|}
\hline \multirow{3}{*}{$\begin{array}{c}\text { No } \\
1\end{array}$} & \multirow{3}{*}{\begin{tabular}{l}
\multicolumn{1}{c}{$\begin{array}{c}\text { Nama } \\
\text { Validator }\end{array}$} \\
Validator \\
1
\end{tabular}} & \multicolumn{8}{|c|}{ Aspek Yang Dinilai } & \multirow{3}{*}{$\begin{array}{c}\begin{array}{c}\text { Jumlah } \\
\text { Skor }\end{array} \\
39\end{array}$} & \multirow{3}{*}{$\begin{array}{c}\text { Rerata } \\
4.88\end{array}$} & \multirow{3}{*}{$\begin{array}{c}\text { Kategori } \\
\text { Sangat } \\
\text { Layak }\end{array}$} \\
\hline & & \multicolumn{3}{|c|}{$\begin{array}{c}\text { Aspek } \\
\text { Petunjuk }\end{array}$} & \multicolumn{2}{|c|}{$\begin{array}{c}\text { Aspek } \\
\text { Isi }\end{array}$} & \multicolumn{3}{|c|}{$\begin{array}{c}\text { Aspek } \\
\text { Bahasa }\end{array}$} & & & \\
\hline & & 5 & 5 & 5 & 4 & 5 & 5 & 5 & 5 & & & \\
\hline 2 & $\begin{array}{l}\text { Validator } \\
2\end{array}$ & 5 & 5 & 5 & 5 & 5 & 5 & 5 & 5 & 40 & 5.00 & $\begin{array}{l}\text { Sangat } \\
\text { Layak }\end{array}$ \\
\hline \multicolumn{11}{|c|}{ Rerata } & 4.94 & $\begin{array}{l}\text { Sangat } \\
\text { Layak }\end{array}$ \\
\hline
\end{tabular}

TABEL III

Rangkuman hasil uji validasi instrument penelitian (Konten)

\begin{tabular}{|c|c|c|c|c|c|c|c|c|c|c|c|c|}
\hline \multirow{3}{*}{$\begin{array}{c}\text { No } \\
1\end{array}$} & \multirow{3}{*}{\begin{tabular}{l}
\multicolumn{1}{c}{$\begin{array}{c}\text { Nama } \\
\text { Validator }\end{array}$} \\
Validator \\
1
\end{tabular}} & \multicolumn{8}{|c|}{ Aspek Yang Dinilai } & \multirow{3}{*}{$\begin{array}{c}\begin{array}{c}\text { Jumlah } \\
\text { Skor }\end{array} \\
39\end{array}$} & \multirow{3}{*}{$\begin{array}{c}\text { Rerata } \\
4.88\end{array}$} & \multirow{3}{*}{$\begin{array}{c}\text { Kategor } \\
\text { Sangat } \\
\text { Layak }\end{array}$} \\
\hline & & \multicolumn{3}{|c|}{$\begin{array}{c}\text { Aspek } \\
\text { Petunjuk }\end{array}$} & \multicolumn{2}{|c|}{$\begin{array}{c}\text { Aspek } \\
\text { Isi }\end{array}$} & \multicolumn{3}{|c|}{$\begin{array}{c}\text { Aspek } \\
\text { Bahasa }\end{array}$} & & & \\
\hline & & 5 & 5 & 4 & 5 & 5 & 5 & 5 & 5 & & & \\
\hline 2 & $\begin{array}{l}\text { Validator } \\
2\end{array}$ & 5 & 5 & 5 & 5 & 5 & 5 & 5 & 5 & 40 & 5.00 & $\begin{array}{l}\text { Sangat } \\
\text { Layak }\end{array}$ \\
\hline \multicolumn{11}{|c|}{ Rerata } & 4.94 & $\begin{array}{l}\text { Sangat } \\
\text { Layak }\end{array}$ \\
\hline
\end{tabular}

TABEL IV

Rangkuman hasil uji validasi konten

\begin{tabular}{|c|l|c|c|}
\hline No & \multicolumn{1}{|c|}{ Butir Pertanyaan } & Nilai & $\begin{array}{c}\text { Skor Yang } \\
\text { diharapkan }\end{array}$ \\
\hline 1 & $\begin{array}{l}\text { Pilihan konten } \\
\text { permasalahan pada } \\
\text { aplikasi ini sudah tepat } \\
\text { dan sesuai dengan } \\
\text { isinya }\end{array}$ & 5 & 5 \\
\hline 2 & $\begin{array}{l}\text { Informasi yang } \\
\text { disampaikan jelas }\end{array}$ & 5 & 5 \\
\hline 3 & $\begin{array}{l}\text { Informasi yang } \\
\text { disampaikan sistematis }\end{array}$ & 5 & 5 \\
\hline
\end{tabular}

\begin{tabular}{|c|c|c|c|}
\cline { 2 - 3 } 4 & $\begin{array}{l}\text { Informasi yang } \\
\text { disampaikan dikemas } \\
\text { dengan menarik }\end{array}$ & 4 & 5 \\
\hline 5 & $\begin{array}{l}\text { Informasi yang } \\
\text { disampaikan actual }\end{array}$ & 5 & 5 \\
\hline 6 & $\begin{array}{l}\text { Objek yang digunakan } \\
\text { sesuai dengan informasi } \\
\text { yang disampaikan }\end{array}$ & 5 & 5 \\
\hline$\quad$ & Jumlah Skor & 29 & 30 \\
\hline Rata-rata & 4.833333 & \\
\hline
\end{tabular}

b. Hasil Uji ISO 25010

a) Hasil Uji Validasi Ahli Media

TABEL V

Rangkuman hasil uji validasi functionality suitability

\begin{tabular}{|c|c|c|c|c|c|c|}
\hline \multirow{2}{*}{$\begin{array}{c}\text { Jawaba } \\
n\end{array}$} & \multicolumn{2}{|c|}{$\begin{array}{l}\text { Skor Oleh } \\
\text { Validator }\end{array}$} & \multirow{2}{*}{$\begin{array}{c}\text { Skor } \\
\text { Mak } \\
\text { S }\end{array}$} & \multirow{2}{*}{$\begin{array}{c}\text { Tota } \\
\text { I } \\
\text { Skor }\end{array}$} & \multirow{2}{*}{$\begin{array}{c}\text { Rerat } \\
\text { a } \\
\text { skor }\end{array}$} & \multirow{2}{*}{$\begin{array}{c}\text { Persentas } \\
\text { e }\end{array}$} \\
\hline & $\begin{array}{l}\text { Validat } \\
\text { or } 1\end{array}$ & $\begin{array}{l}\text { Validat } \\
\text { or } 2\end{array}$ & & & & \\
\hline Ya & 5 & 5 & 10 & 10 & 1 & $100 \%$ \\
\hline Tidak & - & - & - & - & - & - \\
\hline
\end{tabular}

b) Aspek Usability

TABEL VI

Rangkuman penilaian responden pada aspek usability

\begin{tabular}{|c|c|c|c|c|c|c|c|c|c|c|c|c|c|c|}
\hline \multirow{2}{*}{$\begin{array}{l}\mathbf{N} \\
\text { o. }\end{array}$} & \multirow{2}{*}{$\begin{array}{c}\text { Nama } \\
\text { Responden }\end{array}$} & \multicolumn{12}{|c|}{ Butir Pernyataan } & \multirow{2}{*}{$\begin{array}{c}\text { Juml } \\
\text { ah } \\
\text { Skor }\end{array}$} \\
\hline & & 1 & 2 & 3 & 4 & 5 & 6 & 7 & 8 & 9 & $\begin{array}{l}1 \\
0\end{array}$ & $\begin{array}{l}1 \\
1\end{array}$ & $\begin{array}{l}1 \\
2\end{array}$ & \\
\hline 1 & $\begin{array}{l}\text { Responden } \\
1\end{array}$ & 4 & 4 & 4 & 4 & 4 & 4 & 4 & 4 & 4 & 4 & 4 & 4 & 48 \\
\hline 2 & $\begin{array}{l}\text { Responden } \\
2\end{array}$ & 4 & 4 & 4 & 4 & 5 & 4 & 5 & 4 & 4 & 5 & 5 & 5 & 53 \\
\hline 3 & $\begin{array}{l}\text { Responden } \\
3\end{array}$ & 5 & 5 & 5 & 5 & 4 & 4 & 4 & 5 & 5 & 5 & 5 & 5 & 57 \\
\hline 4 & $\begin{array}{l}\text { Responden } \\
4\end{array}$ & 4 & 5 & 5 & 5 & 4 & 4 & 4 & 5 & 5 & 4 & 4 & 4 & 53 \\
\hline 5 & $\begin{array}{l}\text { Responden } \\
5\end{array}$ & 5 & 5 & 5 & 5 & 5 & 5 & 5 & 5 & 4 & 5 & 5 & 5 & 59 \\
\hline 6 & $\begin{array}{l}\text { Responden } \\
6\end{array}$ & 4 & 4 & 4 & 4 & 5 & 5 & 5 & 5 & 5 & 5 & 5 & 5 & 56 \\
\hline 7 & $\begin{array}{l}\text { Responden } \\
7\end{array}$ & 4 & 4 & 5 & 4 & 4 & 4 & 4 & 4 & 5 & 5 & 5 & 4 & 52 \\
\hline 8 & $\begin{array}{l}\text { Responden } \\
8\end{array}$ & 4 & 4 & 4 & 4 & 4 & 5 & 5 & 4 & 4 & 5 & 5 & 4 & 52 \\
\hline 9 & $\begin{array}{l}\text { Responden } \\
9\end{array}$ & 4 & 4 & 4 & 4 & 4 & 4 & 4 & 4 & 4 & 4 & 4 & 4 & 48 \\
\hline $\begin{array}{l}1 \\
0\end{array}$ & $\begin{array}{l}\text { Responden } \\
10\end{array}$ & 4 & 5 & 5 & 5 & 5 & 4 & 3 & 4 & 4 & 4 & 3 & 5 & 51 \\
\hline $\begin{array}{l}1 \\
1\end{array}$ & $\begin{array}{l}\text { Responden } \\
11\end{array}$ & 5 & 5 & 5 & 5 & 5 & 5 & 5 & 5 & 4 & 4 & 4 & 4 & 56 \\
\hline $\begin{array}{l}1 \\
2\end{array}$ & $\begin{array}{l}\text { Responden } \\
12\end{array}$ & 5 & 5 & 5 & 5 & 5 & 4 & 4 & 4 & 5 & 4 & 5 & 4 & 55 \\
\hline $\begin{array}{l}1 \\
3\end{array}$ & $\begin{array}{l}\text { Responden } \\
13\end{array}$ & 5 & 5 & 5 & 5 & 5 & 4 & 5 & 4 & 4 & 4 & 4 & 5 & 55 \\
\hline $\begin{array}{l}1 \\
4\end{array}$ & $\begin{array}{l}\text { Responden } \\
14\end{array}$ & 4 & 5 & 5 & 5 & 5 & 4 & 4 & 4 & 4 & 4 & 4 & 4 & 52 \\
\hline $\begin{array}{l}1 \\
5\end{array}$ & $\begin{array}{l}\text { Responden } \\
15\end{array}$ & 4 & 5 & 5 & 5 & 5 & 4 & 3 & 4 & 4 & 4 & 3 & 5 & 51 \\
\hline $\begin{array}{l}1 \\
6\end{array}$ & $\begin{array}{l}\text { Responden } \\
16\end{array}$ & 5 & 5 & 5 & 5 & 5 & 5 & 5 & 5 & 4 & 4 & 4 & 4 & 56 \\
\hline
\end{tabular}




\begin{tabular}{|c|c|c|c|c|c|c|c|c|c|c|c|c|c|c|}
\hline 1 & $\begin{array}{l}\text { Responden } \\
17\end{array}$ & 5 & 5 & 5 & 5 & 5 & 4 & 4 & 4 & 5 & 4 & 5 & 4 & 55 \\
\hline $\begin{array}{l}1 \\
8\end{array}$ & $\begin{array}{l}\text { Responden } \\
18\end{array}$ & 5 & 5 & 5 & 5 & 5 & 4 & 5 & 4 & 4 & 4 & 4 & 5 & 55 \\
\hline $\begin{array}{l}1 \\
9\end{array}$ & $\begin{array}{l}\text { Responden } \\
19\end{array}$ & 4 & 5 & 5 & 5 & 5 & 4 & 4 & 4 & 4 & 4 & 4 & 4 & 52 \\
\hline $\begin{array}{l}2 \\
0\end{array}$ & $\begin{array}{l}\text { Responden } \\
20\end{array}$ & 5 & 4 & 5 & 5 & 5 & 4 & 4 & 5 & 4 & 5 & 5 & 5 & 56 \\
\hline \multicolumn{14}{|c|}{ Total } & 1072 \\
\hline
\end{tabular}

TABEL VII

Tanggapan Responden

\begin{tabular}{|c|c|c|c|}
\hline Kategori & Interval & Frekuensi & Persentase \\
\hline Sangat Setuju & $51-60$ & 18 & $90 \%$ \\
\hline Setuju & $41-50$ & 2 & $10 \%$ \\
\hline Cukup Setuju & $31-40$ & - & - \\
\hline Tidak Setuju & $21-30$ & - & - \\
\hline Sangat Tidak Setuju & $12-20$ & - & - \\
\hline \multicolumn{2}{|l|}{ TOTAL } & 20 & $100 \%$ \\
\hline
\end{tabular}

\section{B. PEMBAHASAN}

Aplikasi CIKUR ini merupakan aplikasi yang dikembangkan untuk membantu masyarakat penyandang disabilitas tunanetra di SLB Pembina Sulawesi Selatan dalam mengenal ciri-ciri blind code dan mengetahui nominal uang dengan menggunakan smartphone android. Manfaat adanya aplikasi ini dapat mengedukasi ciri-ciri uang blind code yang dibuat resmi oleh Bank Indonesia kepada penyandang disabilitas tunanetra yang dituangkan peneliti dalam aplikasi CIKUR

Pengembangan aplikasi CIKUR menggunakan jenis penelitian dan pengembangan atau research and development (R\&D), dengan model pengembangan prototype. Aplikasi ini juga diuji menggunakan ISO 25010 yang terdiri dari aspek functional suitability, usability, compability dan portability.

Pengujian aspek functional suitability dilakukan dengan menguji fungsionalitas oleh validasi ahli. Validasi dilakukan oleh dua orang dosen ahli dengan cara mengisi kuesioner, kemudian ahli memberikan saran dan tanggapan terhadap sistem yang dikembangkan. Berdasarkan hasil penilaian dua ahli sistem diperoleh persentase $100 \%$, sehingga dapat disimpulkan bahwa perangkat lunak CIKUR memenuhi aspek functionality suitability dan memiliki kualitas yang layak. Pengujian aspek usability dilakukan menggunakan tanggapan pengguna atau user dengan cara memperkenalkan aplikasi CIKUR kepada penyandang disabilitas tunanetra di SLB Pembina Sulawesi Selatan. Kuesioner yang telah divalidasi oleh 2 orang ahli instrumen kemudian dijadikan tanggapan untuk responden. Hasil pengujian aspek usability mendapatkan rerata skor yaitu 4.47 sehingga rerata tersebut masuk dalam kategori sangat baik.
Pengujian aspek compability dilakukan dengan menggunakan smartphone Samsung untuk mengetahui aplikasi CIKUR bisa berjalan baik atau tidak. Apabila komponen dapat bertukar informasi ketika dalam keadaan berbagi lingkungan yang sama dan dapat diakses secara bersamaan dengan baik artinya aplikasi dinyatakan telah memenuhi aspek compability.

Pengujian aspek portability dilakukan dengan menjalankan aplikasi CIKUR pada berbagai macam sistem operasi android. Adapun versi sistem untuk menginstal aplikasi ini yaitu Lollipop (5.1) hingga Oreo (8.1.0).

Berdasarkan hasil dari penelitian

Pengembangan aplikasi CIKUR untuk mengidentifikasi blind code tactile effect terhadap penyandang disabilitas tunanetra di SLB Pembina Sulawesi Selatan menggunakan standar ISO 25010 ditinjau dari aspek functional suitability, usability, compability, dan portability dapat disumpulkan bahwa aplikasi CIKUR dapat digunakan oleh pengguna.

\section{KESIMPULAN DANSARAN}

A. Kesimpulan

Kesimpulan yang dapat diambil berdasarkan data hasil penelitian dan pembahasan mengenai pengembangan aplikasi CIKUR sebagai media edukasi dan sebagai salah satu alternative untuk mengetahui nominal uang Rupiah.

1. Hasil pengembangan dalam penelitian ini berupa media edukasi pada platform android untuk mengidentifikasi nominal uang. Aplikasi CIKUR memiliki komponen utama yaitu: a) Menu Scan, b) Menu about.

2. Hasil kelayakan kualitas aplikasi CIKUR diuji menggunakan standar ISO 25010. Pada aspek functionality Suitability diperoleh persentase 100\% (dapat diterima), hasil pengujian usability dari ujicoba pengguna aplikasi dengan kategori sangat setuju memiliki frekuensi 18 dengan persentase $90 \%$, lalu persentase $10 \%$ dengan kategori setuju memiliki frekuensi 2 responden. Berdasarkan skor tersebut aplikasi dinyatakan layak dan ditanggapi baik oleh pengguna.

3. Hasil tanggapan pengguna Aplikasi CIKUR berdasarkan angket yang diisi oleh responden pada SLB Pembina Sulawesi Selatan menyatakan bahwa sangat setuju dan dapat diterima dengan baik.

B. Saran

Berdasarkan hasil penelitian yang menyatakan bahwa produk sangat baik, namun dalam rangka upaya penyempurnaan produk maka sangat dibutuhkan beberapa saran antara lain: 
Jurnal MediaTIK : Jurnal Media Pendidikan Teknik Informatika dan Komputer

Vol.3 No.1 (Januari 2020)

1. Database marker semua uang rupiah kertas masih ingin ditambahkan.

2. Penambahan fungsi cahaya perlu agar aplikasi CIKUR dapat digunakan dalam keadaan yang gelap sekalipun.

3. Penambahan volume aplikasi

4. Peruntukan aplikasi ini hanya sebatas smartphone android sehingga pengembangan untuk perangkat mobile dengan sistem operasi IOS juga perlu dilakukan

5. Kelemahan Aplikasi CIKUR tidak dapat membedakan uang asli dan uang yang palsu jadi kiranya bagi peneliti lain jika ingin mengembangkan aplikasi ini agar bisa lebih maksimal dan lebih baik dari aplikasi sebelumnya.

\section{DAftar Pustaka}

[1] Azwar, Saifud Azwar, Saifuddin. 2010. Metode Penelitian. Yogyakarta: Pelajar

[2] Arikunto, Suharsimi. 2006. Prosedur Penelitian Suatu Pendekatan Praktik.Jakarta: PT. Rineka Cipta.

[3] Asfari, dkk. 2012. Pembuatan Aplikasi Tata Ruang Tiga Dimensi Gedung Serba Guna Menggunakan Teknologi Virtual Reality [Studi Kasus: Graha ITS Surabaya]. Jurnal Teknik ITS. 1(1) : A540 - A544. (Online) http://ejurnal.its.ac.id/index.php/teknik/article/viewFile/1866/605 diakses pada tanggal 15 juli 2019 .

[4] Acharya, Anal \&Sinha, Devadatta. 2013. Assesing the Quality of $M$ Learning System using ISO/IEC 25010. International Jurnal of Advanced Computer Reaserch (Vol-3 Nomor-3 Tahun 2013).

[5] Andri Koniyo, 2007, Tuntunan Praktis Membangun Sistem Informasi Akuntansi Dengan Visual Basic Dan Microsoft SQL Server, Yogyakarta : ANDI

[6] Bank Indonesia. 2011. Ciri-ciri Keaslian Uang Rupiah Standar Visual Kualitas Rupiah dan Daftar Rupiah Yang Dicabut dan Ditarik Dari Peredaran. Jakarta: Direktorat Pengedaran Uang.

[7] Bank Indonesia. 2016. Kenali Uang Rupiah Anda Tahun Emisi 2016. Jakarta: Direktorat Pengedaran Uang.

[8] Bank Indonesia. 2017. Ciri-ciri Keasl ian Uang Rupiah Tahun Emisi 2016

[9] Gunawan, H., \& Triantoro, A. (2017). Sistem Informasi Pengolahan Rapor Kurikulum 2013 (STUDI KASUS: SMKN 2 PURWOKERTO). Jurnal Terapan Teknologi Informasi, l(1). https://doi.org/10.21460/jutei.2017.11.6

[10]

Hm, Jogiyanto. 1999. Analisis Desain Sistem Informasi: Pendekatan Tersrtuktur Teori dan Praktek Aplikasi Bisnis, Andi Yogyakarta.

[11]

Hidayati, A., Sarwosri, \& Ririd, A. R. (2009). Analisa Pengembangan Model Kualitas Berstruktur Hirarki.

[12]

Loko, Fadilah. 2018. Cara Mengatasi Laptop Lemot. http://androbuntu.com/2018/06/07/cara-mengatasi-laptop-lemot/. Diakses pada tanggal 30 maret 2019.

[13]

P-ISSN 2656-1247 and E-ISSN 2715-5919
Muslimin, Kara. 2012. Uang Dalam Perspektif Ekonomi Islam. Jurnal Assets Vol.2.1.No.1

[14]

Miftahul Huda dan Bunafit Nugroho. 2010. Membuat Aplikasi Database dengan Java, MySQL, dan NetBeans. Pt. Elex Media Komputindo.

[15] Jakarta.

Oktaviani, Devi. 2013. Augmented Reality (AR) dalam bentuk Location Based Service pada Hotel di Kota dan Kabupaten Bekasi dengan

[16] Platform Layar di Android. Jakarta: Universitas Gunadarma.

Pressman, R.S. 2015. Rekayasa Perangkat Lunak: Pendekatan Praktisi [17] Buku 1. Yogyakarta: Andi.

Pakpahan, Fredy S. 2015. Aplikasi Wisata Sumut Memanfaatkan Fasilitas Google Map Pada Smartphone Berbasis Android. Universitas Sumatera [18] Utara. Medan

Suharsimi, (2006). Prosedur Penelitian Suatu Pendekatan Praktek, [19] Jakarta: Penerbit Rineka Cipta

Rahadi, Hana Pricila. 2014. Pengaruh Mekanisme Good Corporate GovernanceTerhadap Praktik Manajemen Laba Di Bursa Efek Indonesia.Jurnalllmu dan Riset Akuntansi . Sekolah Tinggi Ilmu Ekonomi [20] IndonesiaSurabaya Vol.3 No.10.

Sugiyono. 2015. Metode Penelitian Kuantitatif, Kualitatif dan R\&D. [21] Bandung: Alfabeta.

Sugiyono. 2018. Metode Penilitian Kualitatif, Kuantitatif dan $R \& D$.

[22] Bandung: alfabeta, CV Bandung.

Soeherman, Bonnie dan Marion Pinontoan. (2008). Designing [23] Information System. Jakarta : PT. Elex Media Komputindo.

Siyoto, S., \& Sodik, M. A. (2015). Dasar metodologi penelitian. [24] Yogyakarta:Literasi Media Publishing

Widjajantin dkk. 2007. Ortopedagogik Tunanetra 1. Jakarta: Depdikbud Dirjen Dikti. Gata, Windu, Grace Gata, 2013. Sukses Membangun [25] Aplikasi Penjualan denganJava. Elex Media, Jakarta

Yultrina dkk. 2016. Rancang Bangung Mesin Pendeteksi Nominal Uang Rupiah Kertas Dengan Output Suara Dan Penukaran Uang Rupiah [26] Untuk Tunanetra Berbasis Mikrokontroler.

Zahir Zainuddin, dkk. 2016. Pembuatan Aplikasi Tata Ruang Tiga Dimensi Gedung Serba Guna Menggunakan Teknologi Virtual Reality. 